\title{
PENGARUH KESEHATAN DAN KESELAMATAN KERJA, PELATIHAN DAN KERJA TIM TERHADAP KINERJA TENAGA MEDIS DI RUMAH SAKIT BUDI KEMULIAAN BATAM
}

\section{THE EFFECTS OF HEALTH AND SAFETY, TEAM WORK, TRAINING AND TEAMWORK ON HEALTH WORKERS' PERFORMANCE AT BUDI GLORY BATAM HOSPITAL}

\author{
Rahman Hasibuan \\ Program Studi Manajemen Fakultas Ekonomi \\ Universitas Riau Kepulauan \\ Batam, Indonesia \\ rahman.hasibuan@yahoo.com
}

\begin{abstract}
Abstrak
Penelitian ini bertujuan untuk mengetahui pengaruh kesehatan dan keselamatan kerja, pelatihan serta kerja tim terhadap kinerja tenaga medis di rumah sakit Budi Kemuliaan Batam. Metode dalam pnelitian ini adalah menggunakan pendekatan kuantitatif dengan metode penelitian survey yaitu penelitian yang mengambil sampel dari satu populasi dan menggunakan kuisioner sebagai alat pengumpulan data utama. Sampel terdiri dari 75 orang yang dipilih dengan menggunakan teknik purposive sampling. Hasil penelitian menunjukkan bahwa keselamatan dan kesehatan kerja berpengaruh positif dan signifikan dimana diperoleh angka t hitung k3 ( 2.903 ) $>$ dari t tabel 1,994 dengan taraf signifikasi hasil sebesar 0,05 sama dengan 0,05. Pelatihan berpengaruh positif dan signifikan dimana diperoleh angka t hitung pelatihan 2.976> dari t tabel 1,994 dengan taraf signifikasi hasil sebesar 0,04 tersebut $<0,05$. Kerja tim berpengaruh positif dan signifikan dimana diperoleh angka t hitung kerja tim 5,974> dari t tabel 1,994 dengan taraf signifikasi hasil sebesar 0,00 tersebut $<0,05$.maka dapat diambil kesimpulan bahwa kesehatan dan keselamatan kerja, pelatihan dan kerja tim juga berpengaruh positif dan signifikan terhadap kinerja karyawan
\end{abstract}

Kata Kunci : Kesehatan Dan Keselamatan Kerja, Pelatihan, Kerja Tim, Kinerja Tenaga Medis

\section{Abstract}

This study aims to determine the effect of health and safety, training and teamwork on the health workers' performance at Budi Kemuliaan Batam Hospital. The method in this research was quantitative whichi was using survey research method, that was taking sample from a population and using questionnaire as instrument. The sample consisted of 75 health wokers who were selected by using Purposive Sampling technique. The results showed that safety and health had positive and significant effect which obtained t count of K3 (2.903)> from $t$ table 1,994 with significance level of result equal to 0,05 equal to 0,05. The training had a positive and significant effect where $t$ calculated t arithmetic 2,976> from t table 1,994 with significance level of result 0,04 $<0,05$. Team work had a positive and significant influence where $t$ calculated team work count 5,974> from $t$ table 1,994 with significance level of result 0,00<0,05. It can be concluded that health and safety, training and teamwork also had positive effect and significant on employees' performance.

Keywords: Health and Safety, Training, Teamwork, Health Workers’ Performance 


\section{PENDAHULUAN}

Era globalisasi mengharuskan tenaga kesehatan berbenah diri. Peluang dan tantangan yang menghadang harus diterobos (breaktrough) dengan peningkatan mutu dan profesionalisme tenaga kesehatan Indonesia yang hanya dapat dicapai bila tenaga kesehatan Indonesia dalam melakukan pelayanannya sesuai dengan Standar Profesinya.

Rumah sakit merupakan salah satu mata rantai didalam pemberian pelayanan kesehatan serta suatu organisasi dengan sistem terbuka dan selalu berinteraksi dengan lingkungannya untuk mencapai suatu keseimbangan yang dinamis mempunyai fungsi utama melayani masyarakat yang membutuhkan pelayanan kesehatan serta sebagai tempat penelitian berdasarkan surat keputusan. Dalam pemberian pelayanan kesehatan yang optimal di rumah sakit diperlukan sumber daya yang berkualitas. Dengan menggunakan sumber daya yang ada diharapkan rumah sakit dapat menghasilkan suatu output yang maksimal berupa jasa untuk meningkatkan mutu pelayanan. Untuk masalah- masalah tersebut haruslah disadari bahwa keberhasilan rumah sakit antara lain disebabkan sumber daya manusia, sehingga sumber daya manusia dipandang sebagai asset rumah sakit, bahkan merupakan investasi rumah sakit, apabila tenaga tersebut merupakan tenaga yang terampil. Keberhasilan pelayanan di rumah sakit tidak terlepas dari berbagai faktor pelayanan keperawatan yang biasa disebut dengan asuhan keperawatan.

Menurut pedoman Manjamen Kesehatan dan Keselamatan Kerja ( K3 ) di rumah sakit, Depkes ( 2006 ), dalam undang - undang No 23 tahun 1992 tentang kesehatan pasal 23 dinyatakan bahwa upaya Kesehatan dan Keselamatan Kerja (K3) harus diselenggarakan disemua tempat kerja, khususnya tempat kerja yang mempunyai resiko bahaya kesehatan, mudah terjangkit penyakit atau mempunyai karyawan minimal 10 orang. Jika memperhatikan isi dari pasal tersebut, maka jelaslah bahwa rumah sakit termasuk kedalam kriteria tempat kerja dengan berbagai ancaman bahaya yang dapat menimbulkan dampak kesehatan, tidak hanya terhadap para pelaku langsung yang bekerja di rumah sakit, tapi juga terhadap pasien maupun pengunjung rumah sakit. Sehingga sudah seharusnyalah pihak pengelola rumah sakit menerapkan upaya Kesehatan dan Keselamatan Kerja ( K3 ) di Rumah Sakit.

Pada prinsipnya permasalahan timbul karena lemahnya pihak manajemen dalam menjalankan K3 dengan baik dan benar serta rendahnya tingkat kesadaran tenaga medis terhadap pentingnya pelaksanaan K3, pelatihan yang dilakukan terhadap tenaga medis juga kurang merata, tidak semua tenaga medis mendapat kesempatan yang sama untuk mengikuti pelatihan. 
Menurut Febriawan Ardi Nugroho ( 2014 ) Pelatihan mempunyai manfaat jangka panjang yang membantu tenaga medis memiliki tanggung jawab yang lebih besar di waktu yang akan datang. Para tenaga medis harus dilatih dan dikembangkan di bidang masing masing untuk mengurangi dan mempelajari keterampilan yang baru untuk meningkatkan kinerja mereka. Pelatihan merupakan upaya untuk mengembangkan sumber daya manusia, terutama untuk mengembangkan kemampuan intelektual dan kepribadian. Pelatihan juga merupakan bagian dari suatu proses pendidikan yang bertujuan untuk meningkatkan kemampuan dan keterampilan khusus seseorang atau sekelompok orang ( Hariandja : 2002 ).

Masalah yang dihadapi dalam kerja tim adalah iklim kerja yang dirasa masih kurang nyaman, saat ini para tenaga medis sulit untuk melakukan kerjasama yang efektif, beberapa alasan yang disampaikan diantaranya para junior merasa sulit melakukan komunikasi yang baik dengan senior, mereka merasa masih ada jarak dalam menyampaikan pendapat, sehingga ada partisipasi beberapa tenaga medis yang masih rendah dalam setiap diskusi maupun memecahkan masalah dalam tim kerjanya.

Menurut R. Nugrahaning ( 2013 ) Kinerja adalah prestasi kerja atau hasil kerja ( output ) baik kualitas maupun kuantitas yang dicapai sumber daya manusia persatuan periode yang diberikan padanya. Kinerja yang baik sangat diharapkan bagi setiap perusahaan karena kinerja merupakan tolak ukur dalam mengadakan perbandingan antara apa yang diharapkan dengan kaitannya dengan pekerjaan atau jabatan yang telah dipercayakan kepada seseorang ( Nia Indriasari, 2008 ).

\section{Konsep Manajemen Sumber Daya Manusia}

Manajemen Sumber Daya Manusia

Menurut Sedarmayanti ( 2014 ) Manajemen Sumber Daya Manusia (MSDM) adalah kebijakan dan praktik menentukan aspek “ manusia “ atau sumber daya manusia dalam posisi manajemen, termasuk merekrut, menyaring, melatih, memberi penghargaan dan penilaian.

Secara khusus, manajemen sumber daya manusia bertujuan untuk:

1. Memungkinkan organisasi mendapatkan dan mempertahankan karyawan cakap, dapat dipercaya dan memiliki motivasi tinggi, seperti yang diperlukan.

2. Meningkatkan dan memperbaiki kapasitas yang melekat pada manusia kontribusi, kemampuan dan kecakapan mereka. 
3. Mengembangkan sistem kerja dengan kinerja tinggi yang meliputi prosedur perekrutan dan seleksi “yang teliti”, sistem kompensasi dan insentif yang tergantung pada kinerja, pengembangan manajemen secara aktivitas pelatihan yang terkait "kebutuhan bisnis".

4. Mengembangkan praktik manajemen dengan komitmen tinggi yang menyadari bahwa karyawan adalah pihak terkait dalam organisasi bernilai dan membantu mengembangkan iklim kerjasama dan kepercayaan bersama.

\section{Kesehatan Kerja}

Kesehatan kerja merupakan suatu kondisi yang bebas dari gangguan secara fisik dan psikis yang disebabkan oleh lingkungan kerja. Risiko kesehatan dapat terjadi karena adanya faktor-faktor dalam lingkungan kerja yang bekerja melebihi periode waktu yang ditentukan dan lingkungan yang menimbulkan stress atau gangguan fisik. Risiko keselamatan dapat terjadi karena aspek-aspek dari lingkungan kerja yang dapat menyebabkan kebakaran, sengatan aliran listrik, terpotong, luka memar, keseleo, patah tulang, serta kerusakan anggota tubuh, penglihatan dan pendengaran. (Megginson dalam Mangkunegara,2000). Kesehatan kerja merupakan suatu kondisi yang bebas dari ganguan secara fisik dan psikis yang disebabkan oleh lingkungan kerja. Resiko kesehatan dapat terjadi karena adanya faktor faktor dalam lingkungan kerja yang bekerja melebihi periode waktu yang ditentukan dan lingkungan yang menimbulkan stres atau gangguan fisik, M Yani ( 2012 ).

Menurut Atika Puspita Sari ( 2012 ) Wolf Kristen ( 2008 ) mengemukakan bahwa perusahaan perlu memperhatikan kesehatan karyawan untuk memberikan kondisi kerja yang lebih sehat, serta menjadi lebih bertanggung jawab atas kegiatan-kegiatan tersebut, terutama bagi organisasi-organisasi yang mempunyai tingkat kecelakaan yang tinggi.

\section{Keselamatan Kerja}

Keselamatan kerja adalah keselamatan yang berhubungan dengan aktivitas kerja manusia baik pada industri manufaktur, yang melibatkan mesin, peralatan, penanganan material, pesawat uap, bejana bertekanan, alat kerja, bahan dan proses pengolahannya, landasan tempat kerja dan lingkungannya serta cara-cara melakukan pekerjaan, maupun industri jasa, yang melibatkan peralatan berteknologi canggih, seperti lift, eskalator, peralatan pembersih gedung, sarana transportasi, dan lain-lain.

Menurut Atika Puspita Sari ( 2012 ) Keselamatan kerja telah menjadi salah satu hak azasi manusia yang harus dilindungi oleh pemerintah dan dihargai oleh anggota masyarakat lainnya. Tenaga kerja harus memperoleh perlindungan dari berbagai soal di sekitarnya dan 
pada dirinya yang dapat menimpa atau mengganggu dirinya serta pelaksanaan pekerjaannya ( Mondy 2008 ).

\section{Tujuan Kesehatan dan Keselamatan Kerja}

Tujuan Kesehatan dan Keselamatan Kerja menurut Mangkunegara (2002),

1. Agar setiap pegawai mendapat jaminan kesehatan dan keselamatan kerja baik secara fisik, sosial dan psikologis.

2. Agar setiap perlengkapan dan peralatan kerja digunakan sebaik - baiknya dan seektif mungkin.

3. Agar semua hasil produksi dipeliharan keamanannya.

4. Agar adanya jaminan atas pemeliharaan dan peningkatan kesehatan gizi pegawai.

\section{Proses Sistem Manajemen Kesehatan dan Keselamatan Kerja}

Proses Sistem Manajemen Kesehatan dan Keselamatan Kerja menurut H. M Yani ( 2012 ), pelaksanaan Kesehatan dan Keselamatan Kerja di perusahaan sangat tergantung dari rasa tanggung jawab manajemen dan tenaga kerja terhadap tugas dan kewajiban masingmasing serta kerjasama dalam pelaksanaan K3. Proses manajemen K3 meliputi pelaksanaan fungsi-fungsi manajemen di bidang K3 yaitu fungsi perencanaan, pelaksanaan dan pengawasan. Pelaksanaan program K3 sasarannya adalah tempat kerja yang aman dan sehat. Untuk itu semua permasalahan yang menghambat tercapainya tujuan harus diidentifikasi, dievaluasi, dicari penyebab dasarnya untuk kemudian diupayakan cara pemecahan yang paling baik.

\section{Program Kesehatan dan Keselamatan Kerja}

Pengertian program keselamatan kerja menurut Mangkunegara ( 2000 ) Keselamatan Kerja menunjukan pada kondisi yang aman atau selamat dari penderitaan, kerusakan atau kerugian di tempat kerja. Keselamatan Kerja adalah keselamatan yang berkaitan dengan mesin, pesawat, alat kerja, bahan dan proses pengolahannya, landasan tempat kerja dan lingkungannya serta cara-cara melakukan pekerjaan.

Perusahaan juga harus memelihara keselamatan karyawan di lingkungan kerja dan syarat-syarat keselamatan kerja adalah sebagai berikut :

a. Mencegah dan mengurangi kecelakaan.

b. Mencegah, mengurangi dan memadamkan kebakaran.

c. Mencegah dan mengurangi bahaya peledakan. 
d. Memberi kesempatan atau jalan menyelamatkan diri pada waktu kebakaran atau kejadian-kejadian lain yang berbahaya.

e. Memberikan pertolongan pada kecelakaan.

f. Memberi alat-alat perlindungan pada pekerja.

g. Mencegah dan mengendalikan timbul atau menyebarluaskan suhu, kelembaban, debu, kotoran, asap, uap, gas, hembusan angin, cuaca, sinar dan radiasi, suara dan getaran.

h. Mencegah dan mengendalikan timbulnya penyakit akibat kerja, baik fisik maupun psikis, peracunan, infeksi dan penularan.

i. Memperoleh penerangan yang cukup dan sesuai.

j. Menyelenggarakan penerangan udara yang cukup.

k. Memelihara kebersihan, kesehatan dan ketertiban.

l. Memperoleh kebersihan antara tenaga kerja, alat kerja, lingkungan, cara dan proses kerjanya.

\section{Pelatihan}

Menurut Febriawan Ardi Nugroho ( 2014 )Pelatihan ( training ) adalah proses sistematik pengubahan perilaku para karyawan kedalam suatu arah tertentu guna meningkatkan tujuan-tujuan keorganisasian. Menurut Sjafri Mangkuprawira ( 2004 ) dalam H. M Yani ( 2012 ), pelatihan bagi karyawan merupakan sebuah proses mengajarkan pengetahuan dan keahlian tertentu serta sikap agar karyawan semakin terampil dan mampu melaksanakan tanggung jawabnya dengan semakin baik, sesuai dengan standar.

Menurut Sri Langgeng Ratnasari ( 2013 ) Program pelatihan merupakan suatu program yang membantu karyawan dalam membentuk, meningkatkan keterampilan dan tingkah laku, memperbaiki sikap serta pengetahuan sesuai yang diharapkan perusahaan. Simamora ( 2005 ) menyebutkan bahwa pelatihan adalah serangkaian aktivitas yang dirancang untuk meningkatkan keahlian-keahlian, pengetahuan, pengalaman, ataupun perubahan sikap seorang individu. Pelatihan berkenaan dengan perolehan keahlian-keahlian atau pengalaman tertentu.

\section{Kerja Tim}

Menurut Hussaina Mailisa Safitri ( 2012 ) Kerja Tim atau team work didefenisikan oleh Scarnati ( 2001 ) sebagai proses yang memungkinkan orang biasa untuk mencapai hasil yang luar biasa. Tracy ( 2006 ) menyatakan Kerja tim merupakan kegiatan yang dikelola dan dilakukan sekelompok orang yang tergabung dalam satu organisasi. Kerja tim dapat 
meningkatkan kerja sama dan komunikasi di dalam dan di antara bagian-bagian perusahaan. Biasanya kerja tim beranggotakan orang-orang yang memiliki perbedaan keahlian sehingga dijadikan kekuatan dalam mencapai tujuan perusahaan.

\section{Kinerja}

Setiap manusia mempunyai potensi untuk bertindak dalam berbagai bentuk aktivitas, kemampuan bertindak itu dapat diperoleh manusia secara alami ( ada sejak lahir ) atau dipelajari. Walaupun manusia mempunyai potensi untuk berperilaku tertentu tetapi perilaku itu diaktualisasi pada saat-saat tertentu saja. Potensi untuk berperilaku tertentu itu disebut ability ( kemampuan ) sedangkan ekspresi dan potensi lain dikenal sebagai performance ( kinerja ). Menurut Mangkunegara ( 2011 ) kinerja adalah hasil kerja secara kualitas dan kuantitas yang dicapai oleh seorang pegawai dalam melaksanakan tugasnya dengan tanggung jawab yang diberikan kepadanya.

\section{Penilaian Kinerja}

Penilaian Kinerja merupakan suatu fungsi dari motivasi dan kemampuan. Untuk menyelesaikan tugas atau pekerjaan seseorang sepatutnya memiliki derajat kesediaan dan tingkat kemampuan tertentu. Kesediaan dan keterampilan seseorang tidaklah cukup efektif untuk mengerjakan sesuatu tanpa pemahaman yang jelas tentang apa yang dikerjakan dan bagaimana mengerjakannya. Kinerja merupakan perilaku nyata yang ditampilkan setiap orang sebagai prestasi kerja yang dihasilkan oleh karyawan sesuai dengan perannya dalam perusahaan, M Yani (2012 ).

\section{Tujuan Penilaian Kinerja}

Menurut M. Yani ( 2012 ) Suatu perusahaan melakukan penilaian kinerja didasarkan pada 2 alasan pokok, yaitu :

1. Manajer memerlukan evaluasi yang obyektif terhadap kinerja karyawan pada masa lalu yang digunakan untuk membuat keputusan di bidang SDM dimasa yang akan datang.

2. Manajer memerlukan alat yang memungkinkan untuk membantu karyawan memperbaiki kinerja, merencanakan pekerjaan, mengembangkan kemampuan dan keterampilan untuk perkembangan karier dan memperkuat hubungan antar manajer yang bersangkutan dengan karyawannya.

\section{Manfaat Penilaian Kinerja}

Sedarmayanti ( 2007) mengungkapkan manfaat penilaian kinerja sebagai berikut : 
1. Meningkatkan prestasi kerja, dengan adanya penilaian baik pimpinan maupun karyawan memperoleh umpan balik dan mereka dapat memperbaiki pekerjaan / prestasinya.

2. Memberi kesempatan kerja yang adil, penilaian yang akurat dapat menjamin karyawan memperoleh kesempatan menempati sisi pekerjaan sesuai kemampuannya.

3. Kebutuhan pelatihan dan pengembangan, melalui penilaian kinerja, terdeteksi karyawan yang kemampuannya rendah, sehingga memungkinkan adanya program pelatihan untuk meningkatkan kemampuannya.

\section{Kerangka Pemikiran}

Kerangka berfikir merupakan sintesa tentang hubungan antar variabel yang disusun dari berbagai teori yang telah dideskripsikan. Berdasarkan teori-teori yang telah dideskripsikan tersebut, selanjutnya dianalisis secara kritis dan sistematis, sehingga menghasilkan sintesa tentang hubungan antar variabel yang diteliti. Sintesa tentang hubungan variabel tersebut, selanjutnya digunakan untuk merumuskan hipotesis, Sugiyono ( 2014 ).

Pada penelitian ini penulis akan menyelidiki variabel berpengaruh dalam Kesehatan dan Keselamatan Kerja, Pelatihan dan Kerja Tim, sedangkan variabel terpengaruhnya adalah Kinerja tenaga medis itu sendiri. Berdasarkan uraian tersebut maka kerangka pemikiran teoritis dalam penelitian ini dapat digambarkan sebagai berikut :

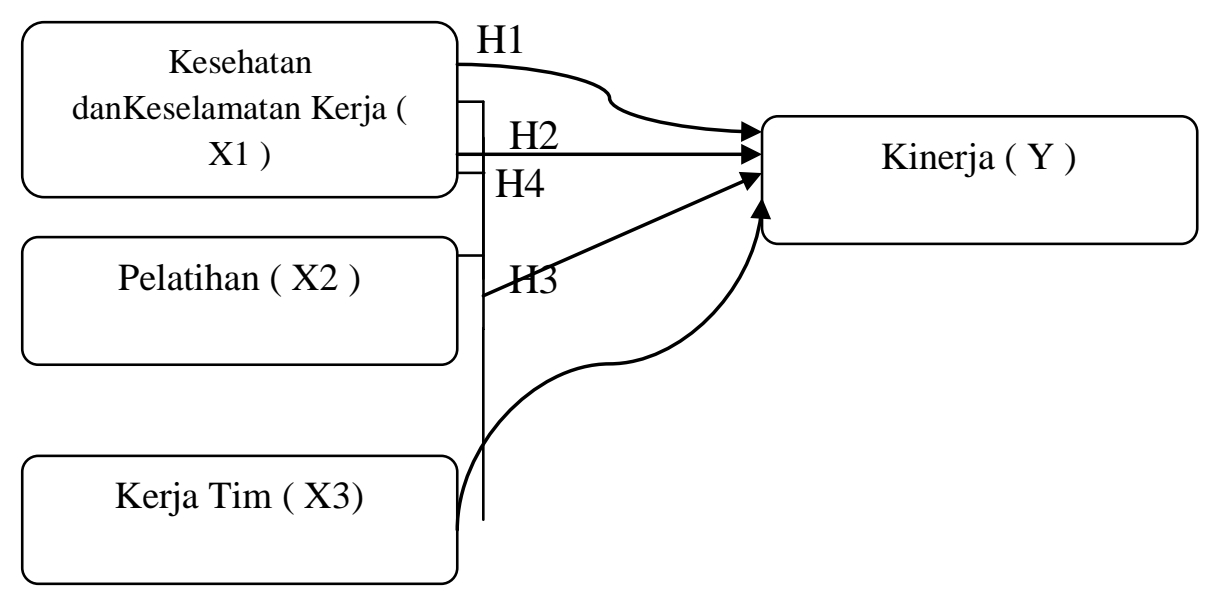

Gambar 1. Kerangka Pemikiran 


\section{METODE PENELITIAN}

Penelitian ini dilakukan di Rumah Sakit Budi Kemuliaan Jln Seraya No I Kampung Seraya, Kota Batam, Kepulauan Riau. Populasi dan sampel diperlukan dalam sebuah penelitian untuk mengumpulkan data dari variabel yang diteliti. Populasi adalah wilayah generalisasi yang terdiri atas obyek / subyek yang mempunyai kualitas dan karakteristik tertentu yang ditetapkan oleh peneliti untuk dipelajari dan kemudian ditarik kesimpulannya, Sugiyono ( 2014 ). Populasi penelitian ini berjumlah 300 (tiga ratus) orang adalah jumlah tenaga medis di Rumah Sakit Budi Kemuliaan Batam.

Sampel adalah bagian dari jumlah dan karakteristik yang dimiliki oleh populasi tersebut. Bila populasi besar, dan peneliti tidak mungkin mempelajari semua yang ada pada populasi, misalnya karena keterbatasan dana, tenaga dan waktu, maka peneliti dapat menggunakan sampel yang diambil dari populasi itu. Apa yang dipelajari sampel itu, kesimpulannya akan dapat diberlakukan untuk populasi. Untuk itu sampel yang diambil dari populasi harus betul-betul representatif ( mewakili ), Sugiyono ( 2014 ).

Teknik pengambilan sampel yang digunakan dalam penelitian ini adalah Sampling Purposive. Menurut Sugiyono ( 2014 ) Sampling Purposive adalah penentuan sampel dengan pertimbangan tertentu. Misalnya akan melakukan penelitian tentang kualitas makanan, maka sampel sumber datanya adalah orang yang ahli makanan, atau penelitian tentang kondisi politik di suatu daerah, maka sampel sumber datanya adalah orang yang ahli politik. Pertimbangan tersebut adalah :

1. Karyawan yang dijadikan sebagai responden adalah karyawan dari Rumah Sakit Budi Kemuliaan Batam.

2. Karyawan yang dijadikan sebagai responden adalah khusus tenaga medis.

Pengambilan sampel harus sesuai dengan kriteria tersebut, karena akan berpengaruh pada variabel yang akan diteliti. Penentuan jumlah sample dihitung dari populasi tertentu yang sudah diketahui jumlahnya.

Berdasarkan Rumus Slovin, maka besarnya penarikan jumlah sampel penelitian adalah

$$
\mathbf{n}=\frac{\mathbf{N}}{\mathbf{1 + \mathbf { N e } ^ { 2 }}}
$$

Keterangan :

$\mathrm{n}=$ Jumlah Sampel 
$\mathrm{N}=$ Populasi

e = Kelonggaran ketidaktelitian karena kesalahan pengambilan sampel yang dapat ditolerir, kemudian dikuadratkan.

Yaitu tingkat kesalahan maximum yang masih bisa ditolerir ( ditentukan $10 \%$ ). Berdasar data yang diperoleh jumlah anggota yang telah diketahui, dapat ditentukan jumlah sampel untuk penelitian ini adalah :

$$
\begin{aligned}
n & =\frac{300}{1+300(0,1)^{2}} \\
& =75
\end{aligned}
$$

Penelitian ini menggunakan pendekatan kuantitatif dengan metode penelitian survey , yaitu penelitian yang mengambil sampel dari satu populasi dan menggunakan kuisioner sebagai alat pengumpulan data utama. Metode penelitian kuantitatif dapat diartikan sebagai metode penelitian yang berlandaskan pada filsafat positivisme, digunakan untuk meneliti pada populasi atau sampel tertentu, teknik pengambilan sampel pada umumnya dilakukan secara random, pengumpulan data menggunakan instrumen penelitian, analisis data bersifat kuantitatif/statistik dengan tujuan untuk menguji hipotesis yang telah ditetapkan, Sugiyono ( $2014)$.

\section{Teknik Pengumpulan Data}

Sekaran ( 2006 ) mengemukakan bahwa pengumpulan data dapat menggunakan sumber data primer dan sumber data sekunder. Sumber data primer mengacu pada informasi yang diperoleh dari tangan pertama oleh peneliti yang berkaitan dengan variabel minat untuk tujuan spesifik studi. Sumber data sekunder mengacu pada informasi yang dikumpulkan dari sumber data yang telah ada. Mengacu pada teori diatas, teknik pengumpulan data dalam penelitian ini terdiri dari data primer dan data sekunder.

Data primer dalam penelitian ini dikumpulkan langsung dari sumber infromasi dengan cara memberikan pertanyaan - pertanyaan melalui kuisioner kepada responden penelitian. Dalam penelitian ini yang menjadi responden penelitian adalah tenaga medis Rumah Sakit Budi Kemuliaan Batam. Data Sekunder yang dikumpulkan dalam penelitian ini diperoleh dari catatan atau dokumentasi Rumah Sakit, informasi dari jurnal-jurnal atau bahan-bahan 
kepustakaan yang berhubungan dengan topik penelitian yang dibahas, yaitu melalui studi pustaka maupun situs internet.

\section{PEMBAHASAN}

Rumah Bersalin dan Balai Pengobatan berusaha untuk memberikan pelayanan terbaik kepada semua lapisan masyarakat, termasuk diantaranya kelompok sosial masyarakat tertinggal (suku laut ) dan masyarakat dari daerah yang sulit dijangkau, kelompok sosial resiko tinggi ( penghuni kompleks WTS, pekerja kasar, buruh industri ). Bahkan saat ini pada lokasi - lokasi tertentu didirikan Balai Pengobatan Pembantu.

Sesuai dengan perkembangan dan tantangan kebutuhan masyarakat akan pelayanan kesehatan yang lebih baik, maka pada tanggal 8 Oktober 1993, bertepatan dengan hari jadinya yang ke-IX, Rumah Bersalin dan Balai Pengobatan mengembangkan diri menjadi Rumah Sakit Budi Kemuliaan Batam.

Rumah Sakit Budi Kemuliaan Batam tetap berpedoman pada tujuan awal serta selalu berusaha meningkatkan peran sertanya dalam pembangunan kesehatan bangsa melalui pelayanan dan penyiapan sumber daya manusia potensial dalam bidang kesehatan. Rumah Sakit Budi Kemuliaan Batam juga menyelenggarakan Pusat Penelitian dan upaya pencegahan penyakit menular seperti HIV/AIDS dan Hepatitis B bekerja sama dengan berbagai instansi terkait dalam dan luar negeri.

\section{Seksi Keperawatan}

Seksi keperawatan bertugas memimpin, merumukan, mengatur, membina, mengendalikan, mengkoordinasikan dan mempertanggung jawabkan tugas-tugas dibidang pelayanan keperawatan yang meliputi asuhan keperawatan rawat inap, rawat jalan dan rawat khusus serta mempertanggung jawabkannya kepada Direktur. Seksi keperawatan membawahi tiga koordinator yaitu :

a. Koordinator Asuhan Keperawatan yang bertugas dalam bidang kegiatan kelancaran pembinaan dan pengembangan asuhan keperawatan

b. Koordinator Logistik Keperawatan yang bertugas untuk membantu kepala seksi keperawatan dalam hal logistik dan sarana keperawatan di semua instalasi Rawat Inap dan Unit Gawat Darurat serta melaporkannya secara rutin kepada Seksi Keperawatan.

c. Koordinator SDM Keperawatan bertugas dalam bidang kegiatan peningkatan pengetahuan dan keterampilan perawat, etika dan mutu perawat. 


\section{Seksi Pelayanan Medis}

Seksi pelayanan medis bertugas mengatur dan mengkoordinasikan semua kebutuhan pelayanan medis dan penunjang medis, melaksanakan pemantauan, pengawasan penggunaan fasilitas serta kegiatan pelayanan medis dan penunjang medis, melakukan pengawasan dan pengendalian penerimaan serta pemulangan pasien. Seksi pelayanan dipimpin oleh seorang kepala seksi yang bertanggung jawab kepada Direktur. Seksi pelayanan membawahi tiga koordinator yaitu :

a. Koordinator Penunjang Medis yang bertugas untuk melayani dan mengkoordinasikan segala kebutuhan Instalasi Rawat Inap, IGD, Instalasi Pemeliharaan sarana dan prasarana rumah sakit, Intalasi Rehabilitasi Medik, Intalasi Farmasi dan Instalasi Gizi.

b. Koordinator P 5 ( Pengawasan, Pengendalian, Penerimaan dan Pemulangan Pasien ) bertugas melakukan pengawasan, pengendalian, penerimaan, dan pemulangan pasien serta tugas-tugas lain yang berhubungan dengan pelayanan terhadap pasien.

Tabel 1. Deskripsi Jawaban Responden atas Variabel Kerja Tim

\begin{tabular}{|c|c|c|c|c|c|c|c|}
\hline \multirow[b]{2}{*}{ No } & \multirow[b]{2}{*}{ Pertanyaan } & \multicolumn{5}{|c|}{ Skor } & \multirow[b]{2}{*}{ Jumlah } \\
\hline & & SS & $S$ & $\mathrm{~N}$ & TS & STS & \\
\hline \multirow[t]{2}{*}{1} & & 23 & 19 & 21 & 12 & 0 & 75 \\
\hline & Butir 1 & $31 \%$ & $25 \%$ & $28 \%$ & $16 \%$ & $0 \%$ & $100 \%$ \\
\hline \multirow[t]{2}{*}{2} & & 23 & 16 & 26 & 10 & 0 & 75 \\
\hline & Butir 2 & $31 \%$ & $21 \%$ & $35 \%$ & $13 \%$ & $0 \%$ & $100 \%$ \\
\hline \multirow[t]{2}{*}{3} & & 20 & 21 & 22 & 12 & 0 & 75 \\
\hline & Butir 3 & $27 \%$ & $28 \%$ & $29 \%$ & $16 \%$ & $0 \%$ & $100 \%$ \\
\hline
\end{tabular}

Tanggapan responden sebagaimana yang terlihat pada tabel menunjukan bahwa sebagian besar responden memberikan tanggapan sangat setuju terhadap variabel Kerja Tim sebanyak400\% dan 483\% Netral.

\section{Deskripsi Variabel Kinerja}

VariabelKinerjapadapenelitianinidiukurmelalui15buahpertanyaanyangmempresentasik anindikator-indikatordarivariabeltersebut.Hasil tanggapan terhadap Kinerja dapat dijelaskan pada tabel 2 berikut:

Tabel 2. Deskripsi Jawaban Responden atas Variabel Kinerja

\begin{tabular}{lllllllll}
\hline \multirow{2}{*}{ No } & \multirow{9}{*}{ Pertanyaan } & \multicolumn{9}{c}{ Skor } & \multirow{2}{*}{ Jumlah } \\
\cline { 3 - 7 } & & SS & & S & N & TS & STS & \\
\hline 1 & 14 & 25 & 29 & 7 & 0 & 75
\end{tabular}




\begin{tabular}{|c|c|c|c|c|c|c|c|}
\hline & Butir 1 & $19 \%$ & $33 \%$ & $39 \%$ & $9 \%$ & $0 \%$ & $100 \%$ \\
\hline \multirow[t]{2}{*}{2} & & 19 & 25 & 26 & 5 & 0 & 75 \\
\hline & Butir 2 & $25 \%$ & $33 \%$ & $35 \%$ & $7 \%$ & $0 \%$ & $100 \%$ \\
\hline \multirow[t]{2}{*}{3} & & 12 & 25 & 32 & 6 & 0 & 75 \\
\hline & Butir 3 & $16 \%$ & $33 \%$ & $43 \%$ & $8 \%$ & $0 \%$ & $100 \%$ \\
\hline \multirow[t]{2}{*}{4} & & 23 & 20 & 25 & 7 & 0 & 75 \\
\hline & Butir 4 & $31 \%$ & $27 \%$ & $33 \%$ & $9 \%$ & $0 \%$ & $100 \%$ \\
\hline \multirow[t]{2}{*}{5} & & 23 & 23 & 24 & 5 & 0 & 75 \\
\hline & Butir 5 & $31 \%$ & $31 \%$ & $32 \%$ & $6 \%$ & $0 \%$ & $100 \%$ \\
\hline \multirow[t]{2}{*}{6} & & 20 & 21 & 28 & 6 & 0 & 75 \\
\hline & Butir 6 & $27 \%$ & $28 \%$ & $37 \%$ & $8 \%$ & $0 \%$ & $100 \%$ \\
\hline \multirow[t]{2}{*}{7} & & 17 & 29 & 25 & 4 & 0 & 75 \\
\hline & Butir 7 & $23 \%$ & $39 \%$ & $33 \%$ & $5 \%$ & $0 \%$ & $100 \%$ \\
\hline \multirow[t]{2}{*}{8} & & 17 & 31 & 18 & 9 & 0 & 75 \\
\hline & Butir 8 & $23 \%$ & $41 \%$ & $24 \%$ & $12 \%$ & $0 \%$ & $100 \%$ \\
\hline \multirow[t]{3}{*}{9} & & 30 & 27 & 15 & 3 & 0 & 75 \\
\hline & Butir 9 & $40 \%$ & $36 \%$ & $20 \%$ & $4 \%$ & $0 \%$ & $100 \%$ \\
\hline & & 16 & 24 & 28 & 7 & 0 & 75 \\
\hline \multirow[t]{2}{*}{10} & Butir 10 & $21 \%$ & $32 \%$ & $38 \%$ & $9 \%$ & $0 \%$ & $100 \%$ \\
\hline & & 20 & 23 & 27 & 5 & 0 & 75 \\
\hline \multirow[t]{2}{*}{11} & Butir 11 & $27 \%$ & $31 \%$ & $36 \%$ & $6 \%$ & $0 \%$ & $100 \%$ \\
\hline & & 23 & 25 & 25 & 2 & 0 & 75 \\
\hline \multirow[t]{2}{*}{12} & Butir 12 & $31 \%$ & $33 \%$ & $33 \%$ & $3 \%$ & $0 \%$ & $100 \%$ \\
\hline & & 14 & 22 & 32 & 7 & 0 & 75 \\
\hline \multirow[t]{2}{*}{13} & Butir 13 & $19 \%$ & $29 \%$ & $43 \%$ & $9 \%$ & $0 \%$ & $100 \%$ \\
\hline & & 13 & 29 & 28 & 5 & 0 & 75 \\
\hline \multirow[t]{2}{*}{14} & Butir 14 & $17 \%$ & $39 \%$ & $37 \%$ & $7 \%$ & $0 \%$ & $100 \%$ \\
\hline & & 31 & 32 & 8 & 4 & 0 & 75 \\
\hline \multirow[t]{3}{*}{15} & Butir 15 & $41 \%$ & $43 \%$ & $11 \%$ & $5 \%$ & $0 \%$ & $100 \%$ \\
\hline & Jumlah & 292 & 381 & 370 & 82 & 0 & 1125 \\
\hline & Persen & $389 \%$ & $508 \%$ & $493 \%$ & $110 \%$ & $0 \%$ & $100 \%$ \\
\hline
\end{tabular}

Sumber: Data Primer yang diolah peneliti,2016

Tanggapan responden sebagaimana yang terlihat pada tabel menunjukan bahwa sebagian besar responden memberikan tanggapan setuju terhadap variabel Kinerja508\% Setuju dan 493\% Netral. Hal ini menunjukkan adanya penilaian terhadap Kinerja yang tinggi oleh tenaga medis di Rumah Sakit Budi Kemuliaan Batam.

\section{Uji Validitas Kinerja}

Tabel 3. Hasil Uji Validitas Kinerja Item-Total Statistics

\begin{tabular}{cccc}
\hline $\begin{array}{c}\text { Butir } \\
\text { Pertanyaan }\end{array}$ & R Hitung & R Kritis & Keterangan \\
\hline Butir1 & 0,555 (positif) & 0,2303 & Valid \\
Butir2 & 0,618 (positif) & 0,2303 & Valid \\
Butir3 & 0,507 (positif) & 0,2303 & Valid \\
Butir4 & 0,681 (positif) & 0,2303 & valid \\
Butir5 & 0,425 (positif) & 0,2303 & Valid \\
Butir6 & 0,562 (positif) & 0,2303 & Valid \\
Butir7 & 0,372 (positif) & 0,2303 & Valid \\
\hline
\end{tabular}




\begin{tabular}{cccc}
\hline Butir8 & 0,440 (positif) & 0,2303 & Valid \\
Butir9 & 0,477 (positif) & 0,2303 & Valid \\
Butir10 & 0,363 (positif) & 0,2303 & Valid \\
Butir 11 & 0,429 (positif) & 0,2303 & Valid \\
Butir 12 & 0,374 (positif) & 0,2303 & Valid \\
& & 0,2303 & Valid \\
Butir 13 & 0,413 (positif) & 0,2303 & Valid \\
& & 0,2303 & Valid \\
Butir 14 & 0,531 (positif) & & \\
Butir 15 & 0,588 (positif) & & \\
Data Primer yang diolah peneliti & &
\end{tabular}

Berdasarkan tabel di atas dapat dilihat bahwa dari semua item pertanyaan variabel Kesehatan dan Keselamatan Kerja, Pelatihan, Kerja Tim dan Kinerja tenaga medis memiliki nilai $r_{\text {hitung }}$ secara keseluruhan setelah dihitung lebih besar dari $r_{\text {tabel }}$, maka dapat diambil kesimpulan bahwa semua item pertanyaan dalam penelitian ini dinyatakan valid.

\section{Uji Reliabilitas}

Tabel 4. Uji Reliabilitas

\begin{tabular}{lll}
\hline \multicolumn{1}{c}{ Variabel } & Cronbach'c $(\boldsymbol{\alpha})$ & Keterangan \\
\hline K3 & 0,690 & Reliabel \\
Pelatihan & 0,864 & Reliabel \\
Kerja Tim & 0,940 & Reliabel \\
Kinerja & 0,773 & Reliabel \\
\hline
\end{tabular}

Sumber : Data primer yang diolah peneliti, 2016

Pada tabel di atas dapat terlihat bahwa nilai Cronbach'c Alpha dari semua item pertanyaan masing-masing variabel tersebut yang telah diuji memiliki nilai di $>0,5$, hal tersebut dapat disimpulkan bahwa seluruh variabel dalam penelitian ini sudah lolos uji reliabilitas dan dinyatakan reliabel.

\section{Uji Asumsi Klasik}

\section{Uji Multikolinieritas}

Seperti yang disebutkan sebelumnya uji multikolinieritas bertujuan untuk menguji apakah model regresi ditemukan kolerasi antar variabel bebas (independen). Model regresi yang baik adalah model regresi yang tidak memiliki kolerasi diantara variabel independen. Salah satu cara mendeteksi ada atau tidaknya multikolinieritas dalam model regresi adalah dilihat dari nilai tolerance dan variance inflation factor (VIF) . Nilai tolerance yang rendah sama dengan nilai VIF yang tinggi (VIF = 1/tolerance). Nilai yang umum dipakai untuk 
menunjukan multikolonieritas adalah nilai tolerance $\leq 0.10$ atau sama dengan nilai $\mathrm{VIF} \geq 10$ Dapat dilihat pada tabel 5. dibawah.

Tabel 5. Hasil Uji Multikoleniaritas (Coefficients ${ }^{a}$ )

\begin{tabular}{lcc}
\hline & \multicolumn{2}{c}{ Collinearity Statistics } \\
\cline { 2 - 3 } Model & Tolerance & VIF \\
\hline 1 (Constant) & & \\
K3 (X1) & 0,991 & 1.010 \\
Pelatihan (X2) & 0,745 & 1.343 \\
Kerja Tim (X3) & 0,746 & 1.340 \\
\hline
\end{tabular}

Sumber: Data primer yang diolah peneliti

\section{Pembahasan}

Berdasarkan hasil pengolahan data primer yang diperoleh melalui kuisioner dari proses penganalisaan secara statistik, dihasilkan beberapa keputusan tentang masalah yang dimunculkan dan telah ditetapkan sebagai hipotesa. Kesimpulan yang dipeoleh adalah hasil analisa data yang telah didapatkan dengan alat ukur yang telah terbukti validitasnya dengan hasil uji validitas menggunakan teknik korelasi. Dengan hasil nilai korelasi ( $r$ ) >0,2303 instrumen terbukti valid. Disamping itu instrument juga telah diukur tingkat kehandalannya ( reliabilitas ) yang dihasilkan $\alpha>0,05$ membuktikan alat ukur reliable untuk dijadikan fasilitas pengumpulan data.

Untuk meyakinkan bahwa persamaan garis regresi yang diperoleh adalah linear dan dapat dipergunakan ( valid ) untuk mencari peramalan, maka akan dilakukan asumsi multikolinearitas, heterokedastisitas dan normalitas. Melalui uji multikolinearitas dihasilkan bahwa terjadi hubungan yang sempurna antara variabel independen dengan regresi dalam bukti nilai VIF $(1343)<10$ dan teleransi 0,745 > 0,1 dapat disimpulkan bahwa terdapat gejala multikolinearitas antar variabel bebas dalam model regresi.

Sedang uji heteroskedastisitas yang dilakukan untuk menguji ketidaksamaan varians dan residual dalam model regresi melalui titik - titik yang menyebar secara acak, tidak membentuk suatu pola tertentu yang jelas, serta tersebar baik di atas maupun di bawah angka 0 ( nol ) pada sumbu $\mathrm{Y}$, hal ini berarti tidak terjadi penyimpangan asumsi klasik heteroskedastisitas pada model regresi yang dibuat, dengan kata lain menerima hipotesis heteroskedastisitas. Dilakukan juga uji normalitas untuk menguji apakah dalam model regresi, variabel independen dan variabel dependen keduanya terdistribusi secara normal atau tidak. Uji normalitas data dalam penelitian dapat dilihat dengan caramemperhatikan titik-titik 
pada Normal P-Plot Regresion Standardized Residual dari variabel dependen.Dengan hasil data menyebar disekitar garis diagonal mengikuti arah garis diagonal, maka model regresi memenuhi asumsi normalitas. Selanjutnya untuk pengujian terhadap hipotesis dalam penelitian ini dijelaskan sebagai berikut :

1. Pengaruh Kesehatan dan Keselamatan Kerja terhadap Kinerja tenaga medis Hasil pengujian hipotesis ( H1 ) membuktikan terdapat pengaruh antara Kesehatan dan Keselamatan Kerja terhadap kinerja tenaga medis. Melalui hasil perhitungan yang telah diperoleh nilai t hitung sebesar $2.903>$ dari t tabel 1,994 dengan taraf signifikasi hasil sebesar 0,05 sama dengan 0,05, dengan demikian Ha diterima dan Ho ditolak. Pengujian secara statistik membuktikan bahwa Keselamatan dan Kesehatan Kerja berpengaruh positif dan signifikan terhadap kinerja tenaga medis.

2. Pengaruh Pelatihan terhadap Kinerja Tenaga Medis

Hasil pengujian hipotesis ( $\mathrm{H} 2$ ) membuktikan terdapat pengaruh antara pelatihan terhadap kinerja tenaga medis. Melalui hasil perhitungan yang telah diperoleh nilai $t$ hitung sebesar 2.976> dari t tabel 1,994 dengan taraf signifikasi hasil sebesar 0,04 tersebut $<0,05$, dengan demikian Ha diterima dan Ho ditolak. Pengujian secara statistik membuktikan bahwa pelatihan berpengaruh positif dan signifikan terhadap kinerja tenaga medis.

3. Pengaruh Kerja Tim terhadap Kinerja tenaga medis.

Hasil pengujian hipotesis ( H3 ) membuktikan terdapat pengaruh antara Kerja Tim terhadap kinerja tenaga medis. Melalui hasil perhitungan yang telah diperoleh nilai t hitung sebesar 5,974> dari t tabel 1,994 dengan taraf signifikasi hasil sebesar 0,00 tersebut $<0,05$, dengan demikian Ha diterima dan Ho ditolak. Pengujian secara statistik membuktikan bahwa Kerja Tim berpengaruh positif dan signifikan terhadap kinerja tenaga medis.

\section{KESIMPULAN DAN SARAN}

\section{Kesimpulan}

Dari pembahasan yang telah diuraikan, maka dapat ditarik kesimpulan sebagai berikut 
1. Variabel Keselamatan dan Kesehatan Kerja berpengaruh positif dan signifikan terhadap kinerja tenaga medis dimana diperoleh angka t hitung K3 ( 2.903 ) > dari t tabel 1,994 dengan taraf signifikasi hasil sebesar 0,05 sama dengan 0,05.

2. Variabel Pelatihan berpengaruh positif dan signifikan terhadap kinerja tenaga medis dimana diperoleh angka t hitung pelatihan 2.976> dari t tabel 1,994 dengan taraf signifikasi hasil sebesar 0,04 tersebut $<0,05$.

3. Variabel Kerja Tim berpengaruh positif dan signifikan terhadap kinerja tenaga medis dimana diperoleh angka t hitung kerja tim 5,974> dari t tabel 1,994 dengan taraf signifikasi hasil sebesar 0,00 tersebut $<0,05$.

4. Dari hasil penelitian terdahulu dapat diambil kesimpulan bahwa Kesehatan dan Keselamatan Kerja, Pelatihan dan Kerja Tim juga berpengaruh positif dan signifikan terhadap Kinerja Karyawan.

\section{Saran}

Berdasarkan kesimpulan yang telah dijelaskan diatas, maka beberapa hal yang mungkin bisa peneliti sarankan khususnya bagi Rumah Sakit Budi Kemuliaan Batam adalah :

1. Pada faktor Keselamatan dan Kesehatan Kerja, penerapan K3 yang sudah berjalan agar dipertahankan dan ditingkatkan lagi, karena resiko - resiko yang dihadapi tenaga medis sewaktu melakukan pekerjaannya sangat rentan diakibatkan tenaga medis kontak langsung dengan pasien, kesadaran akan pentingnya K3 dari tenaga medis juga sangat berperanpenting demi peningkatan kinerja.

2. Pada faktor Pelatihan tidak akan pernah ada kata cukup karena penangananpenanganan penyakit terhadap pasien terus membutuhkan pelatihan agar tenaga medis semakin profesional dan berkompetensi dalam menjalankan tugasnya, dan hendaknya pelatihan diadakan secara merata terhadap seluruh tenaga medis.

3. Pada faktor Kerja Tim, agar tenaga medis tidak pernah mengabaikan variabel ini, pihak manajemen harus memperhatikan masalah dalam hal ini agar kesenjangan antara tenaga medis junior dengan tenaga medis senior tidak ada lagi.

\section{REFERENSI}

Ardi Febriawan,( 2014 ).“Jurnal Pengaruh Pelatihan dan Insentif Terhadap Kinerja Karyawan PT. Bank Danamon Madiun”. Jakarta

Ghozali Imam, ( 2006 ). Statistik Nonparametrik, UNDIP 
Hariandja Tua, ( 2005 ). Manajemen Sumber Daya Manusia, Jakarta : Grasindo.

Langgeng Sri, ( 2013 ). Jurnal Pengaruh Pelatihan terhadap Prestasi kerja di PT Batam.

Mangkunegara Anwar ( 2014 ).Manajemen Sumber Daya manusia, PT Remaja Rosdakarya.

MunirMisbach, ( 2014 ). Analisa Performance Atribut Keselamatan dan Kesehatan Kerja ( K3) Terhadap Peningkatan Kinerja Karyawan.

MailisaHusnaini, ( 2012 ).Jurnal Pengaruh Gaya Kepemimpinan, Kerjasama Tim dan Gaya Komunikasi Terhadap Kepuasan Kerja serta dampaknya terhadap kinerja pegawai pada Sekretariat Daerah Kota Sabang.

Mondy Wayne, ( 2008 ). Manajemen Sumber Daya Manusia , Jakarta : Erlangga.

Nugrahaning, ( 2013 ). Analisis Pengaruh Keselamatan dan Kesehatan Kerja terhadap Konstruksi Pembangunan The Park Solo.

Puspita Atika, ( 2012 ).Jurnal Pengaruh Pelaksanaan Program Keselamatan Kesehatan Kerja Terhadap Produktivitas Kerja Pada Karyawan Engineering BPTangguh, Teluk Bintini, Papua, Jakarta : FSIP UI

Sedarmayanti, ( 2014 ).Manajemen Sumber Daya Manusia, Jakarta : PT Refika Aditama. Sekaran Uma, ( 2006 ). Metode Penelitian Untuk Bisnis 2 Edisi 4, Jakarta :Salemba Empat. Sugiyono, ( 2014 ). Metode Penelitian Bisnis, Bandung : Alfabeta.

Yani M, ( 2012 ).Manajemen Sumber Daya Manusia,Jakarta: Mitra Wacana $\quad$ Media. 